\title{
PENGARUH SELF ASSESSMENT SYSTEM DAN PELAPORAN SURAT PEMBERITAHUAN (SPT) TERHADAP KEPATUHAN WAJIB PAJAK PADA USAHA MIKRO, KECIL, DAN MENENGAH (UMKM) KOTA KENDARI
}

\author{
Dian Mayafaty Rauf \\ Program Studi Ilmu Ekonomi Pascasarjana Universitas Halu Oleo \\ dianmayafaty@yahoo.co.id
}

Ishak Awaluddin

Fakultas Ekonomi dan Bisnis Universitas Halu Oleo ishak.awaluddin@gmail.com

Muntu Abdullah

Fakultas Ekonomi dan Bisnis Universitas Halu Oleo

dula.abdullah@gmail.com

\begin{abstract}
Abstrak
Penelitian ini bertujuan untuk mengetahui Pengaruh Self Assessment System dan Pelaporan Surat Pemberitahuan (SPT) Terhadap Kepatuhan Wajib Pajak Pada Usaha Mikro, Kecil, dan Menengah (UMKM) Kota Kendari. Penelitian ini menggunakan data primer melalui kuesioner. Responden dalam penelitian ini adalah seluruh pelaku UMKM yang ada di Kota Kendari. Variabel dalam penelitian ini adalah Self Assessment System dan Pelaporan SPT sebagai variabel bebas, serta Kepatuhan Wajib Pajak sebagai variabel terikat.

Analisis data yang digunakan dalam penelitian ini adalah tehnik analisis regresi linier berganda yang diolah melalui software IBM SPSS versi 21, yang dijelaskan dengan statistik deskriptif dan statistik inferensial. Berdasarkan hasil penelitian didapatkan hasil pengujian hipotesis menunjukkan bahwa secara parsial self assessment system berpengaruh positif dan signifikan terhadap kepatuhan wajib pajak dengan nilai probability $0.034<0.05$, dan pelaporan SPT berpengaruh positif dan signifikan terhadap kepatuhan wajib pajak dengan nilai probability $0.000<0.05$.
\end{abstract}

Kata Kunci: Self Assessment System, Pelaporan SPT, Kepatuhan Wajib Pajak.

\section{Abstract}

This study aims to examine the Effect of Self Assessment System, Reporting of Notification Letters (SPT), and Taxpayer Understanding Of Taxpayer Compliance in Micro, Small and Medium Enterprises (UMKM) Kendari City. This study uses primary data through questionnaires. Respondents in this study were all UMKM in Kendari City. The variables in this study are Self Assessment System, SPT Reporting, and Taxpayer Understanding as independent variables, and Taxpayer Compliance as the dependent variable.

The data were analyzed using this study is a technique of multiple linear regression analysis processed through IBM SPSS version 21 software, which is explained by descriptive statistics and inferential statistics. Based on the results of the research, the results of hypothesis testing show that partially self assessment system has a positive and significant effect on taxpayer compliance with a probability value of $0.034<0.05$, SPT reporting has a positive and significant effect on taxpayer compliance with a probability value of $0,000<0.05$, and understanding of taxpayers a positive and significant effect on taxpayer compliance with a probability value of $0,000<0.05$.

Keywords: Self Assessment System, SPT Reporting, Taxpayer Compliance.

\section{PENDAHULUAN}

Indonesia merupakan negara berkembang yang memiliki anggaran pendapatan bertumpu pada sektor perpajakan. Kementerian Keuangan mempublikasikan komposisi pajak dalam pendapatan negara tergolong paling besar dibanding pendapatan dari sektor lain, yaitu sebesar 79\% dalam Anggaran Pendapatan dan Belanja Negara (APBN) 2014 
(www.kemenkeu.go.id). Hal ini menunjukkan betapa perkembangan dan pembangunan negara sangat bergantung pada pemasukan dari sektor perpajakan dan menuntut adanya peran aktif masyarakat untuk berpartisipasi dalam menghimpun pajak.

Besarnya pendapatan negara dari sektor perpajakan ditargetkan terus meningkat sehingga diperlukan pula usaha yang lebih untuk mencapainya. Nota Keuangan dan APBN Tahun Anggaran 2014 menyebutkan bahwa pendapatan negara dari Pajak Penghasilan (PPh) nonmigas terus mengalami peningkatan dari Rp. 250,5 triliun (2008) menjadi Rp. 381,6 triliun (2012), atau tumbuh rata-rata $11,1 \%$ per tahun. Peningkatan pendapatan tersebut diimbangi dengan pengupayaan pemerintah melalui berbagai kebijakan yang mendukung kesadaran masyarakat dalam menunaikan kewajiban dalam perpajakan. Beberapa peraturan baru semakin banyak dikeluarkan dengan harapan masyarakat semakin aktif berpartisipasi terutama dalam penghimpunan Pajak Penghasilan (PPh). Hutagaol (2007: 186) mengungkapkan ada beberapa faktor yang mempengaruhi Wajib Pajak dalam pemenuhan kewajiban pajaknya yaitu besarnya penghasilan yang diperoleh, adanya sanksi perpajakan yang diterapkan, persepsi Wajib Pajak atas pengelolaan pendapatan pajak, perlakuan perpajakan yang adil, penegakan hukum, serta ketersediaan database pemerintah. Penelitian Hardiningsih dan Yulianawati (2011: 129-131) menyebutkan faktor-faktor yang berpengaruh pada kepatuhan Wajib pajak yaitu meliputi kesadaran dalam melaksanakan kewajiban perpajakan, pengetahuan perpajakan, pemahaman peraturan perpajakan, persepsi efektivitas sistem perpajakan, kualitas layanan terhadap Wajib Pajak, serta kemauan membayar.

Pajak penghasilan $(\mathrm{PPh})$ merupakan pajak yang melekat pada Wajib Pajak secara langsung sehubungan dengan kemampuan ekonomi yang dimilikinya dan tidak dapat dipindahtangankan pelunasannya. Melihat kepentingan tersebut, pemerintah menerapkan kebijakan tersendiri terkait pengelolaan $\mathrm{PPh}$ ini. Peningkatan pelayanan pemerintah menjadi lebih transparan dan sederhana terkait $\mathrm{PPh}$ yaitu salah satunya melalui implementasi Self Assessment System yang merupakan sistem pemungutan pajak dimana Wajib Pajak memiliki kewenangan dan kewajiban untuk melakukan perhitungan dan pelaporan besarnya pajak yang ditanggungnya secara mandiri.

Self Assessment System merupakan sistem pemungutan pajak dimana negara memberikan kepercayaan, wewenang, tanggung jawab secara langsung kepada masyarakat untuk memenuhi kewajiban perpajakannya, baik dalam perhitungan besarnya pajak terutang dan kredit pajaknya, pembayaran pajak kurang bayar, maupun pelaporan (Diana dan Setiawati, 2010). Maraknya isu negatif pengelolaan pajak di masa lalu masih seringkali membuat masyarakat kurang percaya pada fiskus. Antisipasi pemerintah untuk terus memaksimalkan pengupayaan pendapatan dari sektor perpajakan dikembangkan melalui penerbitan peraturan perhitungan pajak terutang dengan sederhana melalui Peraturan Pemerintah Nomor 46 tahun 2013 tentang Pajak Final 1\% untuk Wajib Pajak dengan peredaran bruto tertentu atau lebih umum disebut PP No. 46 Tahun 2013.

Penelitian Resyniar (2013: 9) menunjukkan bahwa mayoritas para pelaku Usaha Mikro, Kecil, Menengah (UMKM) tidak setuju dengan penerapan PP No. 46 Tahun 2013. Selaras dengan penelitian Resyniar, hasil penelitian Setyaningsih dan Ridwan (2013: 11) menunjukkan bahwa persepsi Wajib Pajak atas PP No. 46 Tahun 2013 ini mendorong ketidakpatuhan Wajib Pajak.

Setiap Wajib Pajak membutuhkan pemahaman yang cukup atas undang-undang dan konsep perpajakan untuk dapat menjalankan kewajiban perpajakan dengan benar (Pravitasari et.al., 2013: 16). Selain itu, sikap Wajib Pajak dalam pelaporan juga memiliki potensi pengaruh terhadap kepatuhan Wajib Pajak. Penerapan PP No. 46 Tahun 2013 dan Self Assessment System merupakan langkah strategis dalam upaya optimalisasi pengelolaan $\mathrm{PPh}$. Namun penerapan kebijakan tersebut hanya akan maksimal dengan adanya partisipasi aktif Wajib Pajak sehingga Wajib Pajak dituntut untuk memiliki pengetahuan dan pemahaman atas peraturan tersebut serta 
Jurnal Progres Ekonomi Pembangunan (JPEP)

Volume 5, Nomor 2. Tahun 2020

Page: $48-59$

http://ojs.uho.ac.id/index.php/JPEP

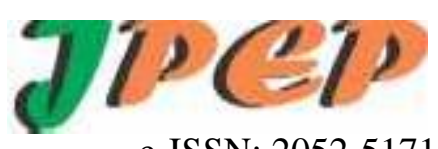

e-ISSN: 2052-5171

memiliki persepsi yang baik atau kepercayaan terhadap fiskus dan praktik perpajakan di Indonesia.

Kota Kendari merupakan salah satu daerah dengan penyebaran Usaha Mikro, Kecil, dan Menengah (UMKM) yang cukup banyak. Dimana pada tahun 2017 jumlah UMKM di Kota Kendari sebesar 13.446 pelaku UMKM dengan 39.136 tenaga kerja yang terbagi Usaha Mikro sebanyak 6.406 usaha dengan jumlah tenaga kerja 11.275 orang, Usaha Kecil sebanyak 4.913 usaha dengan jumlah tenaga kerja 17.290 orang dan Usaha Menengah sebanyak 2.127 usaha dengan 10.571 tenaga kerja. Berdasarkan kenyataan tersebut peneliti bermaksud melakukan penelitian dengan berfokus pada pelaku UMKM di Kota Kendari. Masyarakat di Kota Kendari sebagai pelaku UMKM sebagian besar merupakan subjek dari PP No. 46 Tahun 2013 dimana kebanyakan mereka merupakan pelaku UMKM dalam bidang perdagangan. Namun saat ini penerimaan pajak penghasilan di Kota Kendari belum maksimal. Hal tersebut dikarenakan masih belum maksimalnya proses sosialisasi dan edukasi kepada masyarakat serta masih rendahnya kesadaran sukarela Wajib Pajak dalam memenuhi kewajiban pajaknya.

Hasil penelitan yang dilakukan oleh Megahsari Seftiani Mintje (2016) dan Iga Cahya Shinta Dewi (2014) menyatakan bahwa kesadaran wajib pajak berpengaruh signifikan terhadap kepatuhan wajib pajak. Josephine Nidya Prajogo (2013) dan Ida Ayu Candra Apsari Manuaba (2017) menyatakan bahwa pemahaman wajib pajak berpengaruh terhadap kepatuhan wajib pajak. Septiani Fransisca (2015) menyatakan bahwa enerapan e-spt (independen) berpengaruh secara signifikan terhadap variabel kepatuhan Wajib Pajak. Hasil pengamatan sementara yang dilakukan oleh peneliti bahwa penerimaan negara dari sektor perpajakan masih belum mencapai target yang telah ditetapkan dalam Anggaran Pendapatan dan Belanja Negara (APBN). Selain itu sebagian besar pelaku UMKM di Kota Kendari masih belum patuh dalam memenuhi kewajiban perpajakannya.

Penelitian ini bertujuan sebagai berikut: (1) Mengetahui pengaruh Self Assessment System terhadap Kepatuhan Wajib Pajak pada UMKM Kota Kendari dan (2) Mengetahui pengaruh Pelaporan SPT terhadap Kepatuhan Wajib Pajak pada UMKM Kota Kendari.

\section{TINJAUAN PUSTAKA}

\section{Kepatuhan Wajib Pajak}

Pengertian kepatuhan wajib pajak Menurut Nurmantu dalam Fitri (2012), adalah sebagai berikut: Kepatuhan perpajakan didefinisikan sebagai suatu keadaan dimana Wajib Pajak memenuhi semua kewajiban perpajakan dan melaksanakan hak perpajakannya. Sedangkan Pengertian kepatuhan wajib pajak Menurut Nasucha dalam Ademarta (2014), kepatuhan adalah sebagai berikut: Kepatuhan pada otoritas aturan-aturan, sedangkan kepatuhan dalam perpajakan dapat diartikan sebagai tingkat sampai di mana wajib pajak mematuhi undang-undang perpajakan.

Kepatuhan pelaksanaan PP No.46 Tahun 2013 sangat dipengaruhi oleh beberapa faktor. Kepatuhan diukur melalui kategori yang telah ditetapkan pemerintah melalui Peraturan Menteri Keuangan Nomor.74/PMK.03/2012. Kepatuhan wajib pajak menurut Peraturan Menteri Keuangan Nomor.74/PMK.03/2012 yang disebut wajib pajak patuh adalah wajib pajak yang memenuhi kategori sebagai berikut: (1) Tepat waktu dalam menyampaikan Surat Pemberitahuan; (2) Tidak mempunyai tunggakan untuk semua jenis pajak, kecuali tunggakan pajak yang telah memperoleh izin mengangsur atau menunda pembayaran pajak; (3) Laporan keuangan diaudit oleh akuntan publik atau lembaga pengawasan keuangan pemerintah dengan pendapat wajar tanpa pengecualian selama 3 (tiga) kali berturut-turut dan (4) Tidak pernah dipidana karena melakukan tindak pidana di bidang perpajakan berdasarkan putusan pengadilan yang telah mempunyai kekuatan hukum tetap dalam jangka waktu 5 (lima) tahun terakhir. 
Jurnal Progres Ekonomi Pembangunan (JPEP)

Volume 5, Nomor 2. Tahun 2020

Page: $48-59$

http://ojs.uho.ac.id/index.php/JPEP

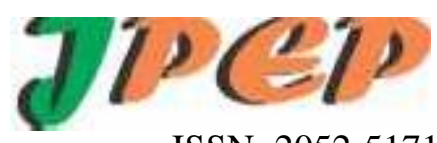

\section{Self Assessment System}

Siti Kurnia Rahayu, Sony Devano (2006) menyatakan bahwa Self Assessment System adalah suatu sistem perpajakan yang memberi kepercayaan kepada wajib pajak untuk memenuhi dan melaksanakan sendiri kewajiban perpajakannya. Menurut Diana Sari (2013) Self Assessment System menyatakan bahwa sistem pemungutan pajak yang memberi wewenang kepada wajib pajak untuk menentukan (menghitung atau menetapkan) sendiri besarnya pajak yang terhutang dan membayarnya sesuai dengan ketentuan yang telah ditetapkan dalam peraturan yang berlaku.

Rimsky K. Judisseno yang dikutip oleh Siti Kurnia Rahayu (2010) menyatakan bahwaSelf assessment system diberlakukan untuk memberikan kepercayaan yang sebesarbesarnya bagi masyarakat guna meningkatkan kesadaran dan peran serta masyarakat dalam menyetorkan pajaknya. Konsekuensinya, masyarakat harus benar-benar mengetahui cara perhitungan pajak dan segala sesuatu yang berhubungan dengan peraturan pemenuhan perpajakan.

Siti Resmi (2011) menyatakan bahwa Self Assessment Sytem adalah sistem pemungutan pajak yang memberi wewenang wajib pajak dalam menentukan sendiri jumlah pajak yang terhutang setiap tahunnya sesuai dengan peraturan perundang-undangan yang berlaku. Sedangkan menurut Mardiasmo (2013) menyatakan bahwa Self Assessment System yaitu suatu sistem pemungutan pajak yang memberi wewenang kepada Wajib Pajakuntuk menentukan sendiri besarnya pajak yang terutang. Dari definisi tersebut dapat dikatakan bahwa Self Assessment System adalah sistem pemungutan pajak yang memberi wewenang, kepercayaan, tanggungjawab kepada Wajib Pajak untuk menghitung, memperhitungkan, membayar, dan melaporkan sendiri besarnya pajak yang harus dibayar.

\section{Surat Pemberitahuan (SPT)}

Surat Pemberitahuan (SPT) adalah surat yang oleh Wajib Pajak (WP) digunakan untuk melaporkan perhitungan dan/atau pembayaran pajak, objek pajak dan/atau bukan objek pajak dan/atau harta dan kewajiban sesuai dengan ketentuan peraturan perundang-undangan perpajakan. Menurut Sari (2013) SPT dapat dibedakan sebagai berikut: (1) SPT Masa, yaitu SPT yang di gunakan untuk melakukan pelaporan atas pembayaran pajak bulanan dan (2) SPT Tahunan, yaitu SPT yang digunakan untuk pelaporan tahunan. Ada beberapa Jenis SPT Tahunan: Wajib Pajak Badan dan Wajib Pajak Orang Pribadi.

Menurut Pasal 3 ayat (3) Undang-Undang Ketentuan Umum dan Tata Cara Perpajakan No. 28 Tahun 2007, batas waktu penyampaian Surat Pemberitahuan (SPT) adalah: (1) Untuk SPT Masa, paling lama 20 (dua puluh) hari setelah akhir Masa Pajak, (2) Untuk SPT Tahunan Pajak Penghasilan Wajib Pajak Orang Pribadi, paling lama 3 (tiga) bulan setelah akhir Tahun Pajak, dan (3) Untuk SPT Tahunan Pajak Penghasilan Wajib Pajak Badan, paling lama 4 (empat) bulan setelah akhir Tahun Pajak.

Pasal 7 ayat (1) UU KUP No. 28 Tahun 2007, apabila Surat Pemberitahuan tidak disampaikan dalam jangka waktu sebagaimana dimaksud dalam Pasal 3 ayat (3) atau batas waktu perpanjangan penyampaian SPT sebagimana dimaksud dalam Pasal 3 ayat (4), dikenai sanksi administrasi berupa denda: (a) SPT Tahunan PPh Orang Pribadi Rp. 100.000 (seratus ribu rupiah), (b) SPT Tahunan PPh Badan Rp. 1.000.000 (satu juta rupiah), (c) SPT Masa PPN Rp. 500.000 (lima ratus ribu rupiah), (d) SPT Masa lainnya Rp. 100.000 (seratus ribu rupiah).

\section{Hubungan Self Assesment System Terhadap Kepatuhan Wajib Pajak}

Hubungan Self Assesment System terhadap kepatuhan wajib pajak menurut Fallan dalam Rahayu (2010) menyatakan bahwa: "Pentingnya aspek perpajakan bagi wajib pajak sangat mempengaruhi sikap wajib pajak terhadap sistem perpajakan yang adil. Dengan kualitas pengetahuan yang semakin baik akan memberikan sikap memenuhi kewajiban dengan benar melalui adanya sistem perpajakan suatu negara yang dianggap adil. Kesadaran wajib pajak akan 
meningkat bilamana dalam masyarakat muncul persepsi positif terhadap pajak. Dengan meningkatnya pengetahuan perpajakan masyarakat melalui pendidikan perpajakan baik formal maupun non formal akan berdampak positif terhadap pemahaman dan kesadaran wajib pajak dalam membayar pajak. Dengan penyuluhan perpajakan secara intensif dan kontinyu akan meningkatkan pemahaman wajib pajak tentang kewajiban membayar pajak sebagai wujud gotong royong nasional dalam menghimpun dana untuk kepentingan pembiayaan pemerintahan dan pembangunan nasional."

Sedangkan menurut Rahayu (2010) kesadaran dan pemahaman warga negara mengenai perpajakan menyatakan bahwa: Rasa nasionalisme tinggi, kepedulian kepada bangsa dan Negara, serta tingkat pengetahuan perpajakan yang memadai, maka secara umum akan makin mudah bagi wajib pajak untuk patuh pada peraturan peraturan perpajakan. Dengan mengutamakan kepentingan negara di atas kepentingan pribadi akan memberi keikhlasan masyarakat untuk patuh dalam kewajiban perpajakannya. Dan dengan pengetahuan yang cukup yang diperoleh karena memiliki tingkat pendidikan yang tinggi tentunya juga akan dapat memahami bahwa dengan tidak memenuhi peraturan maka akan menerima sanksi administrasi maupun pidana fiskal. Maka akan diwujudkan masyarakat yang sadar pajak dan mau memenuhi kewajiban perpajakannya.

\section{Hubungan Pelaporan SPT Terhadap Kepatuhan Wajib Pajak}

Surat Pemberitahuan (SPT) adalah surat yang oleh wajib pajak digunakan untuk melaporkan perhitungan dan/atau pembayaran pajak, objek pajak dan/atau bukan objek pajak, dan/atau harta kewajiban sesuai dengan ketentuan peraturan perundang-undangan perpajakan (pasal 1 angka 11 UU KUP).

Menurut Pandiangan (2008) pengertian e-SPT adalah penyampaian SPT dalam bentuk digital ke KPP secara elektronik atau dengan media komputer. Sesuai dengan keputusan Direktur Jenderal Pajak Nomor Kep88/PJ/2004 tentang penyampaian surat pemberitahuan secara elektronik dalam pasal dijelaskan bahwa wajib pajak dapat menyampaikan surat pemberitahuan secara elektronik melalui perusahaan penyedia jasa aplikasi (Application Service Provider).

Rahayu (2009) menyatakan bahwa pada dasarnya penyampaian SPT secara electronic ini merupakan upaya dari Dirjen Pajak untuk memberikan kemudahan pelayanan bagi Wajib Pajak dalam melaporkan jumlah pajak yang harus dibayarkannya. Karena Wajib Pajak tidak perlu datang secara langsung ke Kantor Pelayanan Pajak untuk memenuhi kewajiban perpajakannya dalam menyampaikan SPT bagi aparat pajak, teknologi electronic mampu memudahkan mereka dalam pengelolaan database karena penyimpanan dokumen-dokumen Wajib Pajak telah dilakukan dalam bentuk digital. Pemerintah berharap dengan adanya teknologi electronic mampu meningkatkan kepatuhan wajib pajak.

Lingga (2013) menyatakan bahwa penggunaan e-SPT dimaksudkan agar semua proses kerja dan pelayanan perpajakan berjalan dengan baik, lancar, akurat serta mempermudah Wajib Pajak dalam melaksanakan kewajiban perpajakannya sehingga kepatuhan akan meningkat. Handayani dan Supadmi (2013) menyatakan bahwa Perkembangan ilmu pengetahuan dan teknologi yang semakin pesat membuat pemerintah mengambil langkah konkrit untuk meningkatkan kepatuhan Wajib Pajak khususnya dalam pelaporan SPT, yakni dengan memberlakukan sistem SPT elektronik (e-SPT). Sistem ini diberlakukan sebagai bentuk peningkatan kualitas pelayanan dari sistem administrasi pajak modern dengan tujuan untuk mempermudah para Wajib Pajak dalam pelaporan SPT. 
Jurnal Progres Ekonomi Pembangunan (JPEP)

Volume 5, Nomor 2. Tahun 2020

Page: 48-59

http://ojs.uho.ac.id/index.php/JPEP

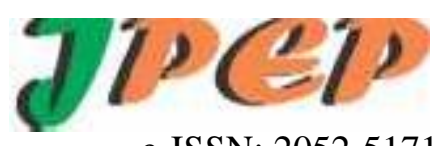

\section{METODE PENELITIAN}

\section{Kerangka Konseptual}

Penelitian ini melibatkan 4 variabel dengan 2 variabel independen dan 1 variabel dependen. Variabel independen meliputi Self Assessment System dan Pelaporan SPT atas PP No. 46 Tahun 2013 sedangkan variabel dependen adalah Kepatuhan Wajib Pajak. Sehingga dapat digambarkan kerangka konsep variabel penelitian sebagai berikut:

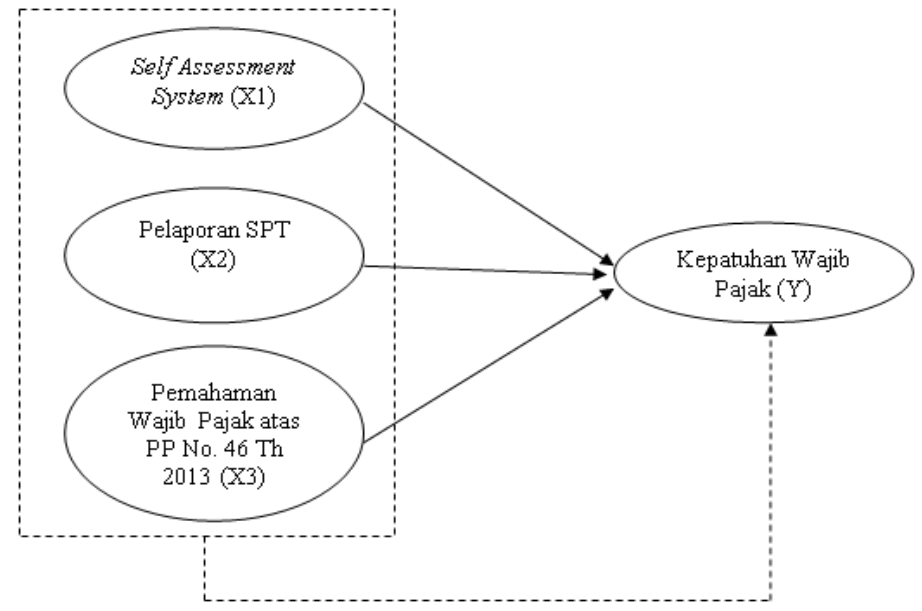

\section{Hipotesis}

\section{Gambar 1. Skema Kerangka Konseptual}

Berdasarkan kerangka konsep yang dibuat, maka rumusan hipotesis dalam penelitian ini sebagai berikut: (1) Diduga Self Assessment System berpengaruh signifikan terhadap Kepatuhan Wajib Pajak pada UMKM Kota Kendari; (2) Diduga Pelaporan SPT berpengaruh signifikan terhadap Kepatuhan Wajib Pajak pada UMKM Kota Kendari.

\section{Jenis Penelitian}

Metode yang digunakan dalam penelitian ini adalah model penelitian deskriptif kuantitatif. Menurut Travers dalam Husein Umar (2001) metode deskriptif merupakan metode yang bertujuan untuk menggambarkan sifat sesuatu yang tengah berlangsung ketika riset dilakukan dan memeriksa sebab-sebab suatu gejala. Penelitian deskriptif mempelajari masalahmasalah dalam masyarakat, serta tata cara yang berlaku dalam masyarakat serta situasi-situasi tertentu, termasuk tentang hubungan, kegiatankegiatan, sikap-sikap, pandangan-pandangan serta proses-proses yang sedang berlangsung dan pengaruh-pengaruh dari suatu fenomena.

\section{Obek Penelitian}

Objek dalam penelitian ini adalah Self Assessment System (X1) dan Pelaporan SPT (X2) sebagai variabel independen, serta Kepatuhan Wajib Pajak (Y) sebagai variabel dependen.

\section{Populasi dan Sampel}

Populasi dalam penelitian ini adalah pelaku Usaha Mikro, Kecil, Menengah (UMKM) di Kota Kendari dengan jumlah pelaku usaha yang terdaftar sebanyak 13.446 jenis usaha. Untuk penentuan jumlah sampel digunakan teknik Slovin. Jadi rentang sampel yang dapat diambil dari teknik Solvin adalah antara 10-20\% dari populasi penelitian. Jumlah populasi dalam penelitian ini adalah sebanyak 13.446 orang pelaku usaha, sehingga presentase kelonggaran yang digunakan adalah $10 \%$ dan hasil perhitungan sampel yang mejadi responden dalam penelitian ini di sesuaikan menjadi sebanyak 100 orang pelaku usaha.

\section{Jenis Data Dan Sumber Data}

Jenis data yang digunakan dalam penelitian ini yaitu data kuantitatif, merupakan data primer yang meliputi pendapat responden mengenai pengaruh self assessment system, pelaporan 
Jurnal Progres Ekonomi Pembangunan (JPEP)

Volume 5, Nomor 2. Tahun 2020

Page: $48-59$

http://ojs.uho.ac.id/index.php/JPEP

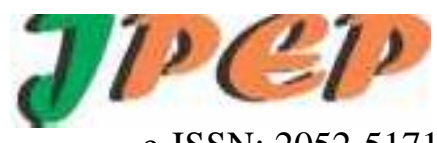

e-ISSN: 2052-5171

SPT, dan pemahaman wajib pajak terhadap kepatuhan wajib pajak pada UMKM di Kota Kendari. Dan data lainnya adalah berupa angka-angka yang diperoleh dari lokasi penelitian dan merupakan data pendukung (sekunder).

\section{Teknik Pengumpulan Data}

Data yang digunakan dalam penelitian ini adalah data primer yang berasal dari sumber utama dan dokumen pendukung lainnya. Pengumpulan data dilakukan dengan menggunakan instrumen berupa kuesioner yang dibagikan kepada objek penelitian, dalam hal ini Wajib Pajak serta melalui dokumentasi. Kuesioner merupakan teknik pengumpulan data dengan cara memberi seperangkat pernyataan dan atau pertanyaan tertulis kepada responden untuk dijawab (Sugiyono, 2012). Jenis kuesioner yang digunakan dalam penelitian ini adalah kuesioner tertutup dimana responden hanya memilih salah satu jawaban yang sudah disediakan baik untuk pernyataan maupun pertanyaan. Hasil dari jawaban responden atas kuesioner yang diberikan akan menjadi data utama.

\section{Skala Pengukuran}

Menurut Sugiyono (2008) skala Likert digunakan untuk mengukur sikap, pendapat, dam persepsi seseorang atau sekelompok orang tentang fenomena sosial. Sehingga untuk mengetahui pengukuran jawaban responden pada penelitian ini yang mana menggunakan instrument penelitian berupa kuisioner, penulis menggunakan metode skala Likert (Likert's Summated Ratings) 5 yaitu sangat setuju, setuju, netral, tidak setuju, dan sangat tidak setuju.

\section{Uji Validitas Dan Realibilitas Validitas}

Validitas merupakan arti seberapa besar ketepatan dan kecermatan suatu alat ukur dalam melakukan fungsi ukurnya. Dikatakan valid apabila kaidah yang digunakan untuk mempertahankan suatu butir adalah korelasi harus positif, dan p paling tinggi adalah 0,05. Kemudian menurut Cronbach, 1970 (Solimun: 2002) koefisien validitas yang memuaskan minimal 0,30 .

\section{Reliabilitas}

Metode pengumpulan data yang digunakan dalam penelitian ini adalah kuesioner/angket, untuk mencari reliabilitasnya digunakan rumus Alpha (Suharsimi 2006:191). Untuk memudahkan perhitungan menurut Ghozali (2006:42) SPSS 16.0 memberikan fasilitas untuk mengukur reliabilitas dengan uji statistik Cronbach Alpha (a). Suatu konstruk atau variabel dikatakan reliabel jika memberikan nilai Cronbach Alpha $>0.60$.

\section{Definisi Operasional Variabel}

Definisi operasional masing- masing variabel adalah sebagai berikut: (1) Kepatuhan Wajib Pajak (Y) didefinisikan sebagai perilaku Wajib Pajak yang merujuk pada tingkat ketaatannya dalam menunaikan kewajiban perpajakan, baik dalam perhitungan, penyetoran, maupun pelaporan pajak terutang; (2) Self Assessment System (X1) adalah sistem pemungutan pajak yang memberi kesempatan kepada wajib pajak untuk membayar pajak sendiri oleh wajib pajak. Keterlibatan Wajib Pajak menjadi hal paling mendasar dari terlaksananya sistem ini karena sistem ini bertolak dari peran aktif Wajib Pajak dalam memenuhi kewajiban pajaknya mulai dari pendaftaran hingga pelaporan, Sony Devano (2006) dan (3) Pelaporan Surat Pemberitahuan (SPT) (X2) adalah surat yang oleh Wajib Pajak (WP) digunakan untuk melaporkan perhitungan dan/atau pembayaran pajak, objek pajak dan/atau bukan objek pajak dan/atau harta dan kewajiban sesuai dengan ketentuan peraturan perundang-undangan perpajakan (pasal 1 angka 11 UU KUP tahun 2007).

\section{Metode Analisis Data}

Analis yang digunakan untuk menjawab hipotesis dalam penelitian ini menggunakan Regresi Linear Berganda dengan menggunakan software SPSS versi 21. 
Jurnal Progres Ekonomi Pembangunan (JPEP)

Volume 5, Nomor 2. Tahun 2020

Page: $48-59$

http://ojs.uho.ac.id/index.php/JPEP

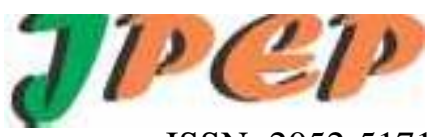

e-ISSN: 2052-5171

\section{HASIL PENELITIAN DAN PEMBAHASAN}

Tabel 1

Hasil Uji Regresi Linear Berganda

\begin{tabular}{|c|c|c|c|c|c|c|}
\hline \multirow[b]{2}{*}{ Model } & & \multicolumn{2}{|c|}{ Unstandardized Coefficients } & $\begin{array}{c}\text { Standardized } \\
\text { Coefficients }\end{array}$ & \multirow[t]{2}{*}{$\mathbf{t}$} & \multirow[t]{2}{*}{ Sig. } \\
\hline & & B & Std. Error & Beta & & \\
\hline 1 & (Constant) & .350 & .197 & & 1.781 & .078 \\
\hline & $\mathrm{X} 1$ & .235 & .056 & .240 & 4.202 & .000 \\
\hline & $\mathrm{X} 2$ & .685 & .054 & .728 & 12.736 & .000 \\
\hline
\end{tabular}

Sumber: Data Primer diolah, 2019.

Berdasarkan hasil Uji pada Tabel 5.1 di atas, maka diperoleh hasil persamaan regresi untuk variabel $\mathrm{X} 1$ dan $\mathrm{X}_{2}$ terhadap $\mathrm{Y}$ sebagai berikut: $\mathrm{Y}=0,350+0,235 \mathrm{X} 1+0,685 \mathrm{X}_{2}$. Diperoleh nilai $\mathbf{a}=0,350$ artinya apabila variabel self assessment system (X1) dan pelaporan spt $\left(\mathrm{X}_{2}\right)$ tidak ada atau tidak dilaksanakan maka nilai kepatuhan wajib pajak sebesar 0,350. Nilai koefisien $X_{1}=0,235$ artinya setiap terjadi kenaikan variabel self assessment system $\left(X_{1}\right)$ sebesar 1 satuan, maka akan meningkatkan kepatuhan wajib pajak (Y) sebesar 0,235 dengan asumsi variabel lain tetap. Demikian pula X2 $=0,685$ artinya setiap terjadi kenaikan variabel pelaporan spt $\left(\mathrm{X}_{2}\right)$ sebesar 1 satuan, maka akan meningkatkan kepatuhan wajib pajak (Y) sebesar 0,685 dengan asumsi variabel lain tetap.

Berdasarkan hasil Uji $\mathrm{t}$ (parsial) diperoleh nilai signifikan $\mathrm{t}$ hitung: variabel self assessment system $\left(\mathrm{X}_{1}\right)$ sebesar 0,000 dan variabel pelaporan spt $\left(\mathrm{X}_{2}\right)$ sebesar 0,000. Dengan sig $\mathrm{t}(<\mathrm{a}=0,05)$ maka variabel self assessment system dan pelaporan spt berpengaruh signifikan terhadap kepatuhan wajib pajak UMKM di kota Kendari.

Tabel 5.2 Hasil Uji-F (ANOVA)

\begin{tabular}{|c|c|c|c|c|c|}
\hline \multicolumn{6}{|c|}{ ANOVA $^{a}$} \\
\hline Model & Sum of Squares & df & Mean Square & $\mathbf{F}$ & Sig. \\
\hline Regression & 37.296 & 2 & 18.648 & 204.559 & $.000^{1}$ \\
\hline Residual & 8.843 & 97 & .091 & & \\
\hline Total & 46.139 & 99 & & & \\
\hline
\end{tabular}

Sumber: Data Primer diolah, 2019.

Berdasarkan hasil Uji F (simultan)diperoleh dengan tingkat signifikasi F sebesar 0,000 karena nilai signifikasi $\mathrm{F}$ lebih kecil dari $\mathrm{a}=0,05$ yang menunjukkan bahwa secara bersamasama atau simultan variabel self assessment system dan pelaporan spt berpengaruh signifikan terhadap kepatuhan wajib pajak, maka model regresi dapat digunakan untuk memprediksikan kepatuhan wajib pajak UMKM di Kota Kendari dengan mempertimbangkan self assessment system dan pelaporan SPT secara simultan berpengaruh signifikan terhadap kepatuhan wajib pajak.

\section{Pembahasan \\ Pengaruh Self Assessment System Terhadap Kepatuhan Wajib Pajak}

Berdasarkan hasil uji statistik menunjukkan bahwa secara parsial Self Assessment System berpengaruh positif dan signifikan terhadap kepatuhan wajib pajak, yang artinya bahwa pelaku usaha UMKM di Kota Kendari sadar akan pentingnya membayar pajak serta para wajib pajak sangat berperan aktif dalam menerima informasi yang disampiakan oleh petugas pajak yang ada di Kota Kendari. Dengan demikian dapat diinterpretasikan bahwa responden menyadari bahwa membayar pajak kesadaran dari kewajiban wajib pajak atau kewajiban setiap warga negara yang harus di laksanakan.

Pengaruh Self Assesment System terhadap kepatuhan wajib pajak menurut Fallan dalam Rahayu (2010:141) menyatakan bahwa: "Pentingnya aspek perpajakan bagi wajib pajak sangat mempengaruhi sikap wajib pajak terhadap sistem perpajakan yang adil. Dengan kualitas pengetahuan yang semakin baik akan memberikan sikap memenuhi kewajiban dengan benar 
melalui adanya sistem perpajakan suatu negara yang dianggap adil. Kesadaran wajib pajak akan meningkat bilamana dalam masyarakat muncul persepsi positif terhadap pajak. Dengan meningkatnya pengetahuan perpajakan masyarakat melalui pendidikan perpajakan baik formal maupun non formal akan berdampak positif terhadap pemahaman dan kesadaran wajib pajak dalam membayar pajak. Dengan penyuluhan perpajakan secara intensif dan kontinyu akan meningkatkan pemahaman wajib pajak tentang kewajiban membayar pajak sebagai wujud gotong royong nasional dalam menghimpun dana untuk kepentingan pembiayaan pemerintahan dan pembangunan nasional."

Temuan penelitian ini diperkuat dengan hasil penelitian terdahulu Neni Nur Fitriani (2017) membuktikan bahwa self assessment system berpengaruh positif dan signifikan terhadap kepatuhan wajib pajak.

\section{Pengaruh Pelaporan SPT Terhadap Kepatuhan Wajib Pajak}

Berdasarkan hasil uji statistik menunjukkan bahwa secara parsial pelaporan SPT berpengaruh positif dan signifikan terhadap kepatuhan wajib pajak, dengan artian bahwa setiap peningkatan terhadap pelaporan SPT maka akan meningkatkan kepatuhan wajib pajak pada UMKM di Kota Kendari. Dengan demikian dapat diinterpretasikan bahwa responden menyadari sanksi pajak sangat diperlukan untuk menciptakan kedisiplinan setiap wajib pajak, sanksi harus dilaksanakan dengan tegas kepada setiap wajib pajak yang melakukan pelanggaran.

Surat Pemberitahuan (SPT) adalah surat yang oleh wajib pajak digunakan untuk melaporkan perhitungan dan/atau pembayaran pajak, objek pajak dan/atau bukan objek pajak, dan/atau harta kewajiban sesuai dengan ketentuan peraturan perundang-undangan perpajakan (pasal 1 angka 11 UU KUP).

Menurut Pandiangan (2008: 35) pengertian e-SPT adalah penyampaian SPT dalam bentuk digital ke KPP secara elektronik atau dengan media komputer. Sesuai dengan keputusan Direktur Jenderal Pajak Nomor Kep88/PJ/2004 tentang penyampaian surat pemberitahuan secara elektronik dalam pasal dijelaskan bahwa wajib pajak dapat menyampaikan surat pemberitahuan secara elektronik melalui perusahaan penyedia jasa aplikasi (Application Service Provider).

Rahayu (2009) menyatakan bahwa pada dasarnya penyampaian SPT secara electronic ini merupakan upaya dari Dirjen Pajak untuk memberikan kemudahan pelayanan bagi Wajib Pajak dalam melaporkan jumlah pajak yang harus dibayarkannya. Karena Wajib Pajak tidak perlu datang secara langsung ke Kantor Pelayanan Pajak untuk memenuhi kewajiban perpajakannya dalam menyampaikan SPT bagi aparat pajak, teknologi electronic mampu memudahkan mereka dalam pengelolaan database karena penyimpanan dokumen-dokumen Wajib Pajak telah dilakukan dalam bentuk digital. Pemerintah berharap dengan adanya teknologi electronic mampu meningkatkan kepatuhan wajib pajak.

Hasil penelitian ini diperkuat oleh penelitian terdahulu yang dilakukan oleh Irmayanti Madewing (2013). Hasil penelitian tersebut menunjukkan bahwa modernisasi sistem administrasi perpajakan yang terdiri dari restrukturisasi organisasi, penyempurnaan proses bisnis dan teknologi informasi, penyempurnaan sumber daya manusia, dan pelaksanaan Good Governance berpengaruh positif dan signifikan terhadap kepatuhan wajib pajak. Hermawan Adiputra (2014), berjudul Pengaruh Tingkat Pemahaman Peraturan Pajak Wajib Pajak dan Kualitas Pelayanan Fiskus Terhadap Kepatuhan Wajib Pajak PPh Pasal 25 Badan. Hasil penelitian tersebut menunjukkan bahwa tingkat pemahaman peraturan Wajib Pajak serta kualitas pelayanan fiskus berpengaruh positif dan signifikan terhadap Kepatuhan Wajib Pajak. 
Jurnal Progres Ekonomi Pembangunan (JPEP)

Volume 5, Nomor 2. Tahun 2020

Page: $48-59$

http://ojs.uho.ac.id/index.php/JPEP

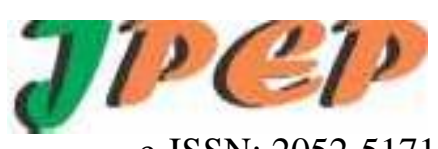

\section{KESIMPULAN DAN SARAN}

\section{Kesimpulan}

Adapun kesimpulan yang dapat ditarik dari penelitian ini adalah: (1) Self Assessment System berpengaruh positif dan signifikan terhadap Kepatuhan Wajib Pajak Pada UMKM Di Kota Kendari yang artinya bahwa semakin baik Self Assesment System maka semakin tinggi tingkat Kepatuhan Wajib Pajak Pada UMKM Di Kota Kendari dan (2) Pelaporan SPT berpengaruh positif dan signifikan terhadap Kepatuhan Wajib Pajak Pada UMKM Di Kota Kendari dengan yang artinya bahwa semakin baik Pelaporan SPT maka akan meningkatkan Kepatuhan Wajib Pajak Pada UMKM Di Kota Kendari.

\section{Saran}

Dari kesimpulan tersebut di atas penulis bermaksud menyampaikan saran-saran sebagai berikut: (1) Diharapkan pihak fiskus dapat mengintensifkan sosialisasi/penyuluhan kepada pelaku UMKM Kota Kendari melaui media cetak maupun media elektronik serta seminarseminar terkait pemahaman wajib pajak atas PP No. 46 tahun 2013 PPh Final 1\% sesuai ketentuan dan tata cara yang ditetapkan. Sehingga, wajib pajak lebih paham dan mengerti mengenai perpajakan, taat dan patuh dalam memenuhi kewajiban perpajakannya, serta tepat waktu dalam pelaporan SPT Tahunan dan (2) Secara keseluruhan semua variabel yang diteliti oleh penulis kiranya bisa menjadi masukan bagi wajib pajak serta pelaku UMKM yang ada di Kota Kendari dan untuk penelitian selanjutnya dapat mengembangkan penelitian ini ataupun menambahkan variabel lainnya diluar faktor yang diteliti yang dianggap berpengaruh terhadap kepatuhan wajib pajak UMKM.

\section{DAFTAR PUSTAKA}

Adiputra, Hermawan. 2014. Pengaruh Tingkat Pemahaman Peraturan Pajak Wajib Pajak dan Kualitas Pelayanan Fiskus Terhadap Kepatuhan Wajib Pajak PPh Pasal 25 Badan. Skripsi dipublikasikan. Universitas Hasanuddin. Makassar

Arfan, Ikhsan Lubis. 2011. Akuntansi Keperilakuan. Edisi 2. Jakarta: Penerbit Salemba Empat

Anastasia, Diana dan Setiawati, Lilis. 2010. Perpajakan Indonesia: Konsep, Aplikasi, \& Penuntun Praktis. Yogyakarta: Penerbit Andi.

Awaluddin, Ishak 2017. Perpajakan: Pembahasan Sesuai Aturan Pelaksanaan Perpajakan Terbaru 2017. Edisi 1. Yogyakarta: Penerbit K-Media.

Departemen Pendidikan Nasional. 2008. Kamus Besar Bahasa Indonesia (KBBI) Edisi 4. Jakarta: Gramedia Pustaka Utama

Diatmika, I Putu Gede. 2013. Penerapan Akuntansi Pajak Atas PP No. 46 Tahun 2013 Tentang PPh Atas Penghasilan dari Usaha Wajib Pajak yang Memiliki Peredaran Bruto Tertentu. Jurnal Akuntansi Profesi ( Vol. 3 No.2, Desember 2013). Hlm. 113-121.

Eunike, Jacklyn Susilo, dan Betri Sirajuddin. 2014. Pemahaman Wajib Pajak Terhadap Peraturan Pemerintah Nomor 46 Tahun 2013 Tentang Pajak UKM (Studi Kasus Pada Wajib Pajak yang Terdaftar di Kantor Pelayanan Pajak Pratama Palembang Ilir Barat). Skripsi dipublikasikan. STIE MDB. Medan

Fidel. 2010. Cara Mudah dan Praktis Memahami Masalah-Masalah Perpajakan. Jakarta: Muara Kencana.

Fransisca, Septiani. 2015. "Analisis Penerapan Pelaporan E-SPT Terhadap Kepatuhan Wajib Pajak Badan Dalam Melaporkan SPT”. Jurnal. Universitas Bina Darma. Palembang

Ghozali, Imam 2011. Aplikasi Analisis Multivariate dengan Program IBM SPSS 19. Semarang: Badan Penerbit UNDIP.

Harahap, Abdul Asri. 2004. Paradigma Baru Perpajakan Indonesia Perspektif Ekonomi. Jakarta: Integrita Dinamika Press.

Husein, Umar. 2001. Riset Akuntansi. Jakarta: PT Gramedia Pustaka Utama. 
Jurnal Progres Ekonomi Pembangunan (JPEP)

Volume 5, Nomor 2. Tahun 2020

Page: $48-59$

http://ojs.uho.ac.id/index.php/JPEP

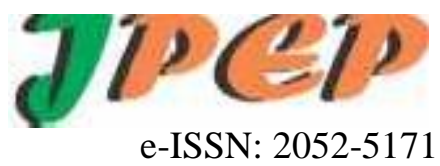

Hutagaol, John, Wing Wahyu dan Arya Pradipta. 2007. Strategi Meningkatkan Kepatuhan Wajib Pajak. Jurnal Akuntabilitas, Hal. 186-193.

Ismawan, Indra. 2001. Memahami Reformasi Perpajakan 2000. Jakarta: PT Elex Media Komputindo.

Lie Liana. 2009. Penggunaan MRA dengan SPSS untuk Menguji Pengaruh Variabel Moderating Terhadap Hubungan antara Variabel Independen dan Variabel Dependen. Jurnal Teknologi Informasi Dinamik, Vol XVI No. 2, Juli 2009, Hal 90-97.

Ling, Jonathan \& Catling, Jonathan. 2012. Psikologi Kognitif. Jakarta: Erlangga.

Madewing, Irmayanti. 2013. Pengaruh Modernisasi Sistem Administrasi Perpajakan Terhadap Kepatuhan Wajib Pajak Pada KPP Pratama Makassar Utara. Skripsi dipublikasikan. Makassar: Universitas Hasanuddin

Mardiasmo. 2011. Perpajakan. rev. ed 2011. Yogyakarta: Penerbit Andi.

Mustika, Elia. 2007. Kajian Empiris tentang Kepatuhan wajib pajak Badan di Perusahaan Industri Pengolahan di Surabaya. Prosiding Simposium Nasional Akuntansi X, Makassar, Juli.

Nur Indrianto dan Bambang Supomo. 1999. Metodologi Penelitian Bisnis untuk Akuntansi \& Manajemen. Yogyakarta: BPFE-Yogyakarta.

Pancawati, Hardiningsih \& Nila Yulianawati. 2011. Faktor-Faktor yang Mempengaruhi Kemauan Membayar Pajak. Dinamika Keuangan dan Perbankan, Vol. 3 No. 1, Nopember 2011, Hal 126-142.

Peraturan Pemerintah Republik Indonesia No. 46 Tahun 2013 tentang Pajak Penghasilan Atas Penghasilan Dari Usaha Yang Diterima Atau Diperoleh Wajib Pajak Yang Memiliki Perdaran Bruto Tertentu (PPh Final $1 \%$ ).

Pravitasari, Narita, Wirawan Endro, Dwi Radianto, Vierly Ananta Upa. 2012. Pengaruh Kebijakan Pajak dan Pemahaman wajib pajak terhadap Kepatuhan Formal Wajib Pajak UMKM Sepatu dan Sandal di Mojokerto. Jurnal Gema Aktualita, Vol. 1 No. 1, Desember 2012.

Rahayu, Siti Kurnia, 2010. Perpajakan Indonesia. Yogyakarta: Graha Ilmu

Rauf, Dian Mayafaty . 2020. Pengaruh Self Assessment System dan Pelaporan Surat Pemberitahuan (SPT) Terhadap Kepatuhan Wajib Pajak Pada Usaha Mikro, Kecil, dan Menengah (UMKM) Kota Kendari. Universitas Halu Oleo. Kendari. 2020

Reed, Stephen K. 2011. Kognisi, Teori dan Aplikasi. Jakarta: Salemba Humanika.

Resyniar, Gandhys. 2013. "Persepsi Pelaku Usaha Mikro, Kecil, dan Menengah (UMKM) terhadap Penerapan PP. 46 Tahun 2013”. Skripsi dipublikasikan. Universitas Brawijaya. Malang.

Rochmat Soemitro. 2004. Asas dan Dasar Perpajakan 2. Bandung: PT Refika Aditama.

Saepudin, Ade. 2012. Pengaruh Pemahaman Akuntansi dan KetentuanPerpajakan serta Transparansi dalam Pajak terhadap Kepatuhan WajibPajak Badan. Skripsi dipublikasikan: Universitas Siliwangi.

Sari, Diana 2013. Konsep Dasar Perpajakan. Bandung: Refika Aditama.

Setyaningsih, Titik dan Ahmad Ridwan. 2013. Persepsi Wajib Pajak UMKM Terhadap Kecenderungan Negosiasi Kewajiban Membayar Pajak Terkait Peraturan Pemerintah Nomor 46 Tahun 2013. Jurnal Prosiding Simposium Nasional Perpajakan (Vol. 4). Hlm. $1-15$.

Siregar, Yuli Anita, Saryadi, dan Sari Listyorini. 2012. "Pengaruh Pelayanan Fiskus dan Pengetahuan Perpajakan Terhadap Kepatuhan Wajib Pajak". Jurnal. Universitas Diponegoro. Semarang.

Sudjana, Nana. 2010. Evaluasi Proses dan Hasil Pembelajaran. Jakarta: Bumi Aksara.

Sugiyono. 2012. Statistika untuk Penelitian. Bandung: CV. Alfabeta 
Jurnal Progres Ekonomi Pembangunan (JPEP)

Volume 5, Nomor 2. Tahun 2020

Page: 48-59

http://ojs.uho.ac.id/index.php/JPEP

Suharsini Arikunto. 2006. Prosedur Penelitian Suatu Pendekatan Praktik. Edisi Revisi VI. Jakarta: Bhineka Cipta.

Sumarna Surapranata. 2005. Analisis, Validitas, Reliabilitas, dan Interpretasi Hasil Tes. Bandung: PT Remaja Rosdakarya

Sutrisno Hadi. 2004. Analisis Regresi. Yogyakarta: Andi Offset.

S. Munawir. 2003. Pajak Penghasilan. Edisi 1. Yogyakarta: BPFE.

Sony Devano, Siti Kurnia Rahayu. 2006. Perpajakan: Konsep, Teori, dan Isu. Jakarta: Prenada Media Group.

Tulus, Tambunan. 2013. Dampak dari Kebijakan "Satu Persen" Pajak pada UMKM. Jurnal Pengkajian Koperasi dan UKM. (Vol. 8 - Oktober 2013). Hlm.1-20.

Undang-Undang Republik Indonesia Nomor 20 tahun 2008 tentang Usaha Mikro, Kecil dan Menengah (UMKM).

Undang-Undang Republik Indonesia Nomor 28 Tahun 2007 tentang perubahan ke tiga atas undang-undang Nomor 6 Tahun 1983 tentang Ketentuan Umum dan Tata Cara Perpajakan.

Waluyo. 2009. Perpajakan Indonesia. Edisi 9. Jakarta: Penerbit Salemba Empat. 